\title{
Homoleptic and heteroleptic complexes of chromium(III) containing 4'- diphenylamino-2,2':6',2"'-terpyridine ligands
}

\author{
Jonas Schönle, Edwin C. Constable, Catherine E. Housecroft,* Alessandro Prescimone and \\ Jennifer A. Zampese
}

Department of Chemistry, University of Basel, Spitalstrasse 51, 4056-Basel, Switzerland Fax: +4161267 1018; E-mail: catherine.housecroft@unibas.ch

\begin{abstract}
Two heteroleptic bis(2,2':6',2"-terpyridine)chromium(III) complexes [Cr(1)(4'-(4tolyl)tpy)] $\left[\mathrm{CF}_{3} \mathrm{SO}_{3}\right]_{3}$ and $\left[\mathrm{Cr}(\mathbf{2})\left(4^{\prime}-(4-\right.\right.$ tolyl)tpy)$]\left[\mathrm{CF}_{3} \mathrm{SO}_{3}\right]_{3}$ in which 1 and $\mathbf{2}$ contain 4'-(4( $N, N$-diphenylamino)phenyl) or 4'-(4-(N,N-di(4-methoxyphenyl)amino)phenyl) domains, respectively, have been prepared and their spectroscopic and electrochemical properties compared with those of $\left[\mathrm{Cr}(4 \text { '-(4-tolyl)tpy })_{2}\right]\left[\mathrm{CF}_{3} \mathrm{SO}_{3}\right]_{3}$ and $\left[\mathrm{Cr}(\mathbf{1})_{2}\right]\left[\mathrm{CF}_{3} \mathrm{SO}_{3}\right]_{3}$. The single crystal structure of $\left[\mathrm{Cr}\left(4^{\prime}-(4-\text { tolyl }) \text { tpy }\right)_{2}\right]\left[\mathrm{CF}_{3} \mathrm{SO}_{3}\right]_{3} \cdot 2 \mathrm{MeCN}$ is presented, and the effects of accommodating three triflate anions and two $\mathrm{MeCN}$ molecules per cation are discussed in terms of related structures. The coordination of $\mathbf{1}$ or $\mathbf{2}$ to chromium(III) red-shifts the ILCT band and this band exhibits a negative solvatochromic effect in some solvents. However, in $\mathrm{H}_{2} \mathrm{O}$, MeOH, DMSO and DMF, the tpy ligands are labile; spectroscopic data for a study of $\left[\mathrm{Cr}(2)\left(4 '-(4-\right.\right.$ tolyl)tpy) $]\left[\mathrm{CF}_{3} \mathrm{SO}_{3}\right]_{3}$ are consistent with the formation of $[\mathrm{Cr}(4$ '$\left.\mathrm{Xtpy})(\mathrm{Solv})_{3}\right]^{3+}(\mathrm{Solv}=$ solvent $)$ rather than complete ligand displacement or a ligand redistribution.
\end{abstract}

Keywords: Chromium(III); 2,2':6',2"-terpyridine; solvatochromic; absorption spectra; heteroleptic complex 


\section{Introduction}

Although large numbers of metal complexes containing $2,2^{\prime}: 6^{\prime}, 2^{\prime \prime}$-terpyridine (tpy) metalbinding domains have been reported in the past 80 years, those with chromium(III) remain underexplored since the homoleptic $\left[\mathrm{Cr}(\operatorname{tpy})_{2}\right]^{\mathrm{n}}(\mathrm{n}=+3,+2,+1,0,-1)$ complexes were described in the 1960s $[1,2,3,4,5,6]$. In 2012, Sproules, Wieghardt and coworkers proposed that in the series $\left[\mathrm{Cr}(\operatorname{tpy})_{2}\right]\left[\mathrm{PF}_{6}\right]_{\mathrm{n}}$ with $\mathrm{n}=3,21,0$, all one-electron redox processes are ligand-based with the chromium centre remaining in the +3 oxidation state [7]. This and other photophysical and electrochemical investigations of complexes having $\left\{\mathrm{Cr}(\operatorname{tpy})_{2}\right\}^{3+}$ cores have dealt with homoleptic complexes $[8,9,10,11,12,13,14,15,16]$. The complexes excited some interest as potential catalysts for photoelectrochemical water-splitting with the observation that in the solid state water molecules were located close to the metal centre in pockets created by the two orthogonal tpy ligands $[17,18]$. We recently showed that heteroleptic $\left[\mathrm{Cr}\left(4^{\prime}-\mathrm{Xtpy}\right)\left(4^{\prime}-\mathrm{Y} \text { tpy }\right)\right]^{3+}$ complexes can be conveniently accessed using the general method shown in Scheme 1, and demonstrated that these complexes do not behave as typical kinetically inert $\mathrm{d}^{3}$ species [19]. We now describe the preparation and properties of chromium(III) complexes incorporating ligands 1 and $\mathbf{2}$ (Scheme 2). The extended $\pi$-systems and peripheral diphenylamine domains in $\mathbf{1}$ and $\mathbf{2}$ provide a facile means of tuning the photophysical properties of the $\left\{\mathrm{Cr}(\operatorname{tpy})_{2}\right\}^{3+}$ complex.

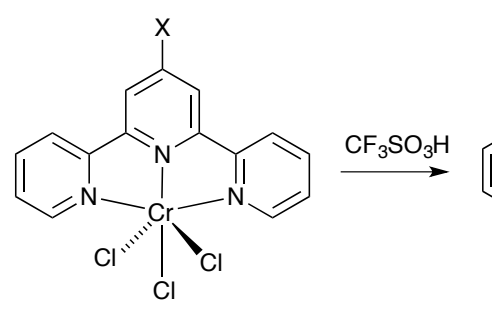

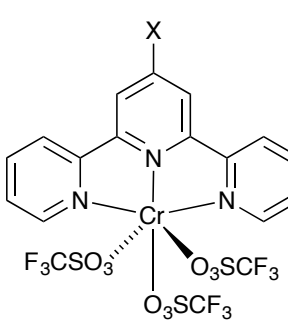

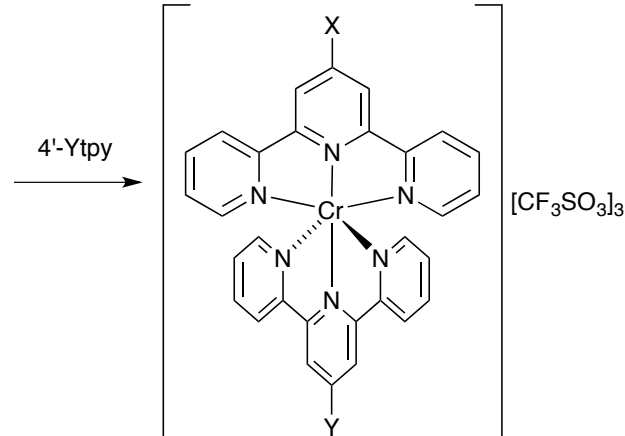

Scheme 1. General route to heteroleptic $\left[\mathrm{Cr}\left(4^{\prime}-\mathrm{Xtpy}\right)\left(4^{\prime}-\mathrm{Ytpy}\right)\right]\left[\mathrm{CF}_{3} \mathrm{SO}_{3}\right]_{3}$ complexes. 
<smiles>[2H]c1ccc(N(c2ccc(P)cc2)c2ccc(-c3cc(-c4ccccn4)nc(-c4ccccn4)c3)cc2)cc1</smiles>

$\begin{array}{ll}1 & R=H \\ 2 & R=O M e\end{array}$<smiles>O=[N+]([O-])c1ccc(-c2cc(-c3ccccn3)nc(-c3ccccn3)c2)cc1</smiles>

4'-(4-tolyl)tpy

Scheme 2. Structures of ligands.

\section{Experimental}

\subsection{General}

${ }^{1} \mathrm{H}$ and ${ }^{13} \mathrm{C}$ NMR spectra were recorded on a Bruker Avance III-500 spectrometer with chemical shifts referenced to residual solvent peaks $(\partial(\mathrm{TMS})=0 \mathrm{ppm})$. Absorption spectra were recorded on a Cary 5000 spectrophotometer on an Agilent Technologies UV-Visble 8453 spectrophotometer. Electrochemical measurements were made on a $\mathrm{CH}$ Instruments $900 \mathrm{~B}$ potentiostat using glassy carbon, platinum wire and a silver wire as the working, counter, and pseudo reference electrodes, respectively. Samples were dissolved in HPLC grade MeCN $\left(10^{-4}\right.$ to $\left.10^{-5} \mathrm{~mol} \mathrm{dm}^{-3}\right)$ containing $0.1 \mathrm{~mol} \mathrm{dm}^{-3}\left[{ }^{\mathrm{n}} \mathrm{Bu}_{4} \mathrm{~N}\right]\left[\mathrm{PF}_{6}\right]$ as supporting electrolyte; all solutions were degassed with argon. $\mathrm{Cp}_{2} \mathrm{Fe}$ was used as internal reference added at the end of experiments.

The compounds 4'-(4-tolyl)-tpy [20], 1 [21] and 2 [21] were prepared as reported.

\section{$2.2 \quad\left[\mathrm{Cr}(\mathbf{1}) \mathrm{Cl}_{3}\right]$}

Anhydrous $\mathrm{CrCl}_{3}(188 \mathrm{mg}, 1.18 \mathrm{mmol})$ and $1(731 \mathrm{mg}, 1.53 \mathrm{mmol})$ were suspended in EtOH (15 mL). Granulated zinc $(16.9 \mathrm{mg}, 0.259 \mathrm{mmol})$ was added, and then the reaction 
mixture was heated at reflux for $6 \mathrm{~h}$, after which it was filtered, leaving excess zinc in the reaction flask. The precipitated $\left[\mathrm{Cr}(\mathbf{1}) \mathrm{Cl}_{3}\right]$ was collected on the filter-frit, washed with EtOH and used in the next step without further purification. IR: (solid, $v / \mathrm{cm}^{-1}$ ) 501 (s), $519(\mathrm{~m}), 612(\mathrm{w}), 650(\mathrm{w}), 661(\mathrm{~s}), 690(\mathrm{~s}), 695(\mathrm{~s}), 719(\mathrm{w}), 728(\mathrm{~s}), 751(\mathrm{~s}), 790(\mathrm{~s}), 827$ (w), $834(\mathrm{~s}), 890(\mathrm{~m}), 899(\mathrm{w}), 1017(\mathrm{w}), 1026(\mathrm{~s}), 1034(\mathrm{w}), 1066(\mathrm{w}), 1078(\mathrm{w}), 1099$ (w), $1186(\mathrm{w}), 1205(\mathrm{~m}), 1244(\mathrm{~s}), 1262(\mathrm{w}), 1271(\mathrm{w}), 1289(\mathrm{w}), 1338(\mathrm{~m}), 1367(\mathrm{w})$, $1411(\mathrm{~m}), 1436(\mathrm{w}), 1446(\mathrm{w}), 1467$ (m), $1489(\mathrm{~m}), 1520(\mathrm{~m}), 1547$ (w), $1568(\mathrm{~m}), 1576$ (s), 1582 (s), 1603 (m), 3059 (w), 3061 (w), 3998 (w). Found C 62.57, H 4.07, N 9.07; $\mathrm{C}_{33} \mathrm{H}_{24} \mathrm{Cl}_{3} \mathrm{CrN}_{4}$ requires $\mathrm{C} 62.43, \mathrm{H} 3.81, \mathrm{~N} 8.82$.

\section{$2.3 \quad\left[\mathrm{Cr}(\mathbf{1})\left(\mathrm{O}_{3} \mathrm{SCF}_{3}\right)_{3}\right]$}

$\left[\mathrm{Cr}(\mathbf{1}) \mathrm{Cl}_{3}\right](75.0 \mathrm{mg}, 0.118 \mathrm{mmol})$ was dissolved in $\mathrm{CF}_{3} \mathrm{SO}_{3} \mathrm{H}(0.4 \mathrm{~mL}, 4.4 \mathrm{mmol})$ and the dark red solution was stirred overnight at room temperature. The mixture was then cooled to $0{ }^{\circ} \mathrm{C}$ and $\mathrm{Et}_{2} \mathrm{O}(20 \mathrm{~mL})$ was added, yielding a dark red precipitate. The solid was separated by filtration, washed with $\mathrm{Et}_{2} \mathrm{O}$ and dried in air. $\left[\mathrm{Cr}(\mathbf{1})\left(\mathrm{O}_{3} \mathrm{SCF}_{3}\right)_{3}\right]$ was isolated as a dark red solid (72.8 mg, 0.0746 mmol, 67.8 \%). Found C 43.96, H 2.71, N 6.03; $\mathrm{C}_{36} \mathrm{H}_{24} \mathrm{CrF}_{9} \mathrm{~N}_{4} \mathrm{O}_{9} \mathrm{~S}_{3}$ requires $\mathrm{C} 44.31, \mathrm{H} 2.48$, N 5.74.

\section{$2.4 \quad\left[\mathrm{Cr}(\mathbf{1})_{2}\right]\left[\mathrm{CF}_{3} \mathrm{SO}_{3}\right]_{3}$}

A mixture of $\left[\mathrm{Cr}(\mathbf{1})\left(\mathrm{CF}_{3} \mathrm{SO}_{3}\right)_{3}\right](50.0 \mathrm{mg}, 51.2 \mu \mathrm{mol})$ and $1(26.9 \mathrm{mg}, 56.4 \mu \mathrm{mol})$ in $\mathrm{MeCN}$ $(2 \mathrm{~mL})$ was heated at reflux for $7 \mathrm{~h}$. The crude product was recrystallized from $\mathrm{EtOH}$ and $\left[\mathrm{Cr}(\mathbf{1})_{2}\right]\left[\mathrm{CF}_{3} \mathrm{SO}_{3}\right]_{3}$ was isolated as a dark red solid (18.2 mg, $\left.12.5 \mu \mathrm{mol}, 24.4 \%\right)$. IR: (solid, v/cm ${ }^{-1}$ ) $503(\mathrm{~s}), 570(\mathrm{~m}), 635(\mathrm{~s}), 661(\mathrm{~m}), 691(\mathrm{~m}), 717(\mathrm{~m}), 749(\mathrm{~m}), 786(\mathrm{~m}), 829$ (m), 1026 (s), 1068 (m), 1094 (m), 1120 (m), 1142 (s), 1198 (s), 1222 (s), 1240 (s), 1332 
(m), $1366(\mathrm{~m}), 1418(\mathrm{~m}), 1439(\mathrm{~m}), 1476(\mathrm{~s}), 1520(\mathrm{~m}), 1568(\mathrm{~s}), 1575(\mathrm{~s}), 1605(\mathrm{~m}), 3075$

(w), 3497 (w). Found C 56.24, H 3.64, N 7.83; $\mathrm{C}_{69} \mathrm{H}_{48} \mathrm{CrF}_{9} \mathrm{~N}_{8} \mathrm{O}_{9} \mathrm{~S}_{3} \cdot \mathrm{H}_{2} \mathrm{O}$ requires C 56.36, H 3.43, N 7.62.

\section{$2.5 \quad\left[\mathrm{Cr}\left(4^{\prime}-(4-\right.\right.$ tolyl $)$ tpy $\left.) \mathrm{Cl}_{3}\right]$}

The compound was prepared by the same procedure as $\left[\mathrm{Cr}(\mathbf{1}) \mathrm{Cl}_{3}\right]$, starting with anhydrous $\mathrm{CrCl}_{3}$ (761 mg, $\left.4.76 \mathrm{mmol}\right)$ and 4'-(4-tolyl)tpy (2.00 g, $\left.6.18 \mathrm{mmol}\right)$ suspended in EtOH (60 $\mathrm{mL})$. Granulated zinc $(68.2 \mathrm{mg}, 1.05 \mathrm{mmol})$ was added and the mixture was heated at reflux for $4.25 \mathrm{~h}$. [Cr(4'-(4-tolyl)tpy) $\left.\mathrm{Cl}_{3}\right]$ precipitated and was collected on a filter-frit, washed with EtOH and used in the next step without further purification. IR: (solid, $v / \mathrm{cm}^{-}$ 1) $501(\mathrm{~s}), 519(\mathrm{~m}), 612(\mathrm{w}), 650(\mathrm{w}), 661(\mathrm{~s}), 690(\mathrm{~s}), 695(\mathrm{~s}), 719(\mathrm{w}), 728(\mathrm{~s}), 751(\mathrm{~s})$, $790(\mathrm{~s}), 827(\mathrm{w}), 834(\mathrm{~s}), 890(\mathrm{~m}), 899(\mathrm{w}), 1017(\mathrm{w}), 1026(\mathrm{~s}), 1034(\mathrm{w}), 1066(\mathrm{w}), 1078$ (w), $1099(\mathrm{w}), 1186(\mathrm{w}), 1205(\mathrm{~m}), 1244(\mathrm{~s}), 1262(\mathrm{w}), 1271(\mathrm{w}), 1289(\mathrm{w}), 1338(\mathrm{~m})$, 1367 (w), $1411(\mathrm{~m}), 1436(\mathrm{w}), 1446(\mathrm{w}), 1467$ (m), 1489 (m), $1520(\mathrm{~m}), 1547(\mathrm{w}), 1568$ (m), 1576 (s), 1582 (s), 1603 (m), 3059 (w), 3061 (w), 3998 (w). Found C 54.96, H 3.86, N 8.58; $\mathrm{C}_{22} \mathrm{H}_{17} \mathrm{Cl}_{3} \mathrm{CrN}_{3}$ requires $\mathrm{C}$ 54.85, $\mathrm{H} 3.56, \mathrm{~N} 8.72$.

\section{$2.6 \quad\left[\mathrm{Cr}(\mathbf{1})\left(4^{\prime}-(4-\right.\right.$ tolyl $)$ tpy $\left.)\right]\left[\mathrm{CF}_{3} \mathrm{SO}_{3}\right]_{3}$}

[Cr(4'-(4-tolyl)tpy)Cl $]$ (91.9 mg, $0.191 \mathrm{mmol})$ was dissolved in $\mathrm{CF}_{3} \mathrm{SO}_{3} \mathrm{H}(1.7 \mathrm{ml}, 7.6$ mmol) and the dark red solution was stirred at room temperature overnight. The mixture was then cooled to $0{ }^{\circ} \mathrm{C}$ and $\mathrm{Et}_{2} \mathrm{O}(20 \mathrm{~mL})$ was added to precipitate $\left[\mathrm{Cr}\left(4{ }^{\prime}-(4-\right.\right.$ tolyl)tpy $\left.)\left(\mathrm{O}_{3} \mathrm{SCF}_{3}\right)_{3}\right]$. The product was separated by filtration, washed with $\mathrm{Et}_{2} \mathrm{O}$ and dried under a flow of $\mathrm{N}_{2}$, before being dissolved in $\mathrm{MeCN}(10 \mathrm{~mL})$. This solution was added to a flask containing $1(100 \mathrm{mg}, 0.210 \mathrm{mmol})$. The reaction mixture was heated at reflux for 
$5.5 \mathrm{~h}$, after which time solvent was removed. The product was purified by recrystallization from $\mathrm{EtOH}$ and was washed with $\mathrm{Et}_{2} \mathrm{O} .\left[\mathrm{Cr}(\mathbf{1})\left(4^{\prime}-(4-\right.\right.$ tolyl)tpy) $]\left[\mathrm{O}_{3} \mathrm{SCF}_{3}\right]_{3}$ was isolated as a dark red solid (236 mg, 0.182 mmol, 95.2 \%). IR: (solid, v/ $\mathrm{cm}^{-1}$ ) 573 (m), 635 (s), 662 (m), $693(\mathrm{~m}), 725(\mathrm{w}), 755(\mathrm{~m}), 786(\mathrm{~m}), 823(\mathrm{w}), 846(\mathrm{w}), 885(\mathrm{w}), 1026(\mathrm{~s}), 1068(\mathrm{w})$, 1096 (m), 1147 (s), 1198 (m), 1222 (s), 1244 (s), 1336 (w), 1367 (w), 1423 (m), 1464 (m), 1475 (m), 1478 (m), 1520 (w), 1538 (m), 1564 (m), 1569 (m), 1579 (m), 1602 (m), 3071 (w), 3498 (w). Found C 51.99, H 3.36, N 7.42; $\mathrm{C}_{58} \mathrm{H}_{41} \mathrm{CrF}_{9} \mathrm{~N}_{7} \mathrm{O}_{9} \mathrm{~S}_{3} \cdot 2 \mathrm{H}_{2} \mathrm{O}$ requires C 52.17, H 3.40, N 7.34.

\section{$2.7 \quad\left[\mathrm{Cr}(2)\left(4^{\prime}-(4-\right.\right.$ tolyl)tpy) $]\left[\mathrm{CF}_{3} \mathrm{SO}_{3}\right]_{3}$}

The method was as for $\left[\mathrm{Cr}(\mathbf{1})(4\right.$ '-(4-tolyl)tpy) $]\left[\mathrm{CF}_{3} \mathrm{SO}_{3}\right]_{3}$, starting with $[\mathrm{Cr}(4$ '-(4tolyl)tpy)Cl$\left.)_{3}\right](34.8 \mathrm{mg}, 72.2 \mu \mathrm{mol})$ and $\mathrm{CF}_{3} \mathrm{SO}_{3} \mathrm{H}(0.5 \mathrm{ml}, 5.6 \mathrm{mmol})$ in the first step, and then $2(42.6 \mathrm{mg}, 79.4 \mu \mathrm{mol})$ and a reaction time of $6 \mathrm{~h}$ in the second step. $\left[\mathrm{Cr}(2)\left(4 '-(4-\right.\right.$ tolyl)tpy) $]\left[\mathrm{O}_{3} \mathrm{SCF}_{3}\right]_{3}$ was isolated as a dark red solid $(85.7 \mathrm{mg}, 63.1 \mu \mathrm{mol}$, 43.7\%). Found $\mathrm{C} 52.77, \mathrm{H} 3.85, \mathrm{~N} 6.99 ; \mathrm{C}_{60} \mathrm{H}_{45} \mathrm{CrF}_{9} \mathrm{~N}_{7} \mathrm{O}_{11} \mathrm{~S}_{3}$ requires $\mathrm{C} 53.02, \mathrm{H} 3.34, \mathrm{~N}$ 7.21 .

\section{$2.8 \quad\left[\mathrm{Cr}\left(4^{\prime}-(4-\text { tolyl }) \text { tpy }\right)_{2}\right]\left[\mathrm{CF}_{3} \mathrm{SO}_{3}\right]_{3}$}

The method was as for $\left[\mathrm{Cr}(\mathbf{1})(4\right.$ '-(4-tolyl)tpy) $]\left[\mathrm{O}_{3} \mathrm{SCF}_{3}\right]_{3}$, starting with $[\mathrm{Cr}(4$ '-(4tolyl)tpy)Cl $\mathrm{Cl}_{3}$ (164 $\left.\mathrm{mg}, 0.341 \mathrm{mmol}\right)$ and $\mathrm{CF}_{3} \mathrm{SO}_{3} \mathrm{H}(1.2 \mathrm{~mL}, 14 \mathrm{mmol})$ in the first step, and then 4'-(4-tolyl)tpy $(121 \mathrm{mg}, 0.375 \mathrm{mmol})$ and a reaction time of $6.5 \mathrm{~h}$ in the second step. The product precipitated during the reaction and was separated by filtration and recrystallized from hot $\mathrm{MeCN}$. [Cr(4'-(4-tolyl)tpy $\left.)_{2}\right]\left[\mathrm{CF}_{3} \mathrm{SO}_{3}\right]_{3}$ was isolated as an orange solid (302 mg, $0.263 \mathrm{mmol}, 77.0 \%$ ). IR: (solid, n/cm-1) 500 (s), 505 (s), 517 (s), 
$529(\mathrm{~m}), 572(\mathrm{~m}), 613(\mathrm{~m}), 625(\mathrm{~s}), 634(\mathrm{~s}), 662(\mathrm{w}), 693(\mathrm{w}), 727(\mathrm{w}), 778(\mathrm{~m}), 788(\mathrm{~m})$, 823 (m), 949 (w), 996 (m), 1027 (s), 1097 (w), 1116 (m), 1138 (m), 1158 (s), 1210 (m), $1222(\mathrm{~m}), 1249(\mathrm{~s}), 1363(\mathrm{w}), 1406(\mathrm{w}), 1435(\mathrm{w}), 1478(\mathrm{w}), 1533(\mathrm{w}), 1539(\mathrm{w}), 1601(\mathrm{~s})$, 1618 (w), 3066 (w). Found C 49.34, H 3.40, N 8.70; $\mathrm{C}_{47} \mathrm{H}_{34} \mathrm{CrF}_{9} \mathrm{~N}_{6} \mathrm{O}_{9} \mathrm{~S}_{3} \cdot \mathrm{MeCN}$ requires $\mathrm{C}$ 49.58, H 3.14, N 8.26.

\subsection{Crystallography}

Single crystal data were collected on a Bruker APEX-II diffractometer with data reduction, solution and refinement using the programs APEX [22] and SHELX-13 [23]. The structural diagrams and structure analysis were carried out using Mercury v. 3.0.1 or 3.3 $[24,25]$.

[Cr(4'-(4-tolyl)tpy) $\left.)_{2}\right]\left[\mathrm{CF}_{3} \mathrm{SO}_{3}\right]_{3} \cdot 2 \mathrm{MeCN}: \mathrm{C}_{51} \mathrm{H}_{40} \mathrm{CrF}_{9} \mathrm{~N}_{8} \mathrm{O}_{9} \mathrm{~S}_{3}, M=1228.12$, yellow needle, monoclinic, space group $C 2 / c, a=14.5535(8), b=17.1633(11), c=21.9247(14)$ $\AA, \beta=108.308(4)^{\circ}, U=5199.3(6) \AA^{3}, Z=4, D_{\mathrm{c}}=1.569 \mathrm{Mg} \mathrm{m}^{-3}, \mu(\mathrm{Cu}-\mathrm{K} \alpha)=3.802$ $\mathrm{mm}^{-1}, T=123 \mathrm{~K}$. Total 17034 reflections, 4644 unique, $R_{\text {int }}=0.0512$. Refinement of 3700 reflections (404 parameters) with $I>2 \sigma(I)$ converged at final $R 1=0.0383(R 1$ all data $=$ $0.0539), w R 2=0.0906(w R 2$ all data $=0.0984)$, gof $=1.019$.

\section{$3 \quad$ Results and discussion}

\subsection{Synthesis of the chromium(III) complexes}

The ligands 4'-(4-tolyl)tpy, 1 and $\mathbf{2}$ were prepared as previously reported [20,21]. The synthesis of related pairs of homoleptic and heteroleptic coplexes containing a $\left\{\mathrm{Cr}(\operatorname{tpy})_{2}\right\}^{3+}$ core was achieved using the general method shown in Scheme 1. [Cr(4'-(4-tolyl)tpy) $\left.\mathrm{Cl}_{3}\right]$ and $\left[\mathrm{Cr}(\mathbf{1}) \mathrm{Cl}_{3}\right]$ were prepared by treating $\mathrm{CrCl}_{3}$ with the appropriate ligand in the presence of zinc in ethanol [19], and subsequent reaction with triflic acid gave [Cr(4'-(4- 
tolyl)tpy $\left.)\left(\mathrm{O}_{3} \mathrm{SCF}_{3}\right)_{3}\right]$ and $\left[\mathrm{Cr}(\mathbf{1})\left(\mathrm{O}_{3} \mathrm{SCF}_{3}\right)_{3}\right]$, respectively. Although these complexes may be isolated, it is more convenient to prepare them as required and use them in situ for reaction with a second equivalent of tpy ligand. Scheme 3 summarizes the formation of $\left[\mathrm{Cr}(4 \text { '-(4-tolyl)tpy })_{2}\right]\left[\mathrm{CF}_{3} \mathrm{SO}_{3}\right]_{3},\left[\mathrm{Cr}(\mathbf{1})\left(4\right.\right.$ '-(4-tolyl)tpy)] $\left[\mathrm{CF}_{3} \mathrm{SO}_{3}\right]_{3}$ and $[\mathrm{Cr}(\mathbf{2})(4$ '-(4tolyl)tpy) $]\left[\mathrm{CF}_{3} \mathrm{SO}_{3}\right]_{3}$. The homoleptic complex $\left[\mathrm{Cr}(\mathbf{1})_{2}\right]\left[\mathrm{O}_{3} \mathrm{SCF}_{3}\right]_{3}$ was prepared in an analogous manner by treatment of $\left[\mathrm{Cr}(\mathbf{1})\left(\mathrm{O}_{3} \mathrm{SCF}_{3}\right)_{3}\right]$ with ligand $\mathbf{1}$. Elemental analyses for the homoleptic and heteroleptic triflate salts were satisfactory. Attempts to record their MALDI-TOF or electrospray mass spectra did not yield interpretable data, a problem encountered with other bis(tpy) chromium(III) complexes [19].

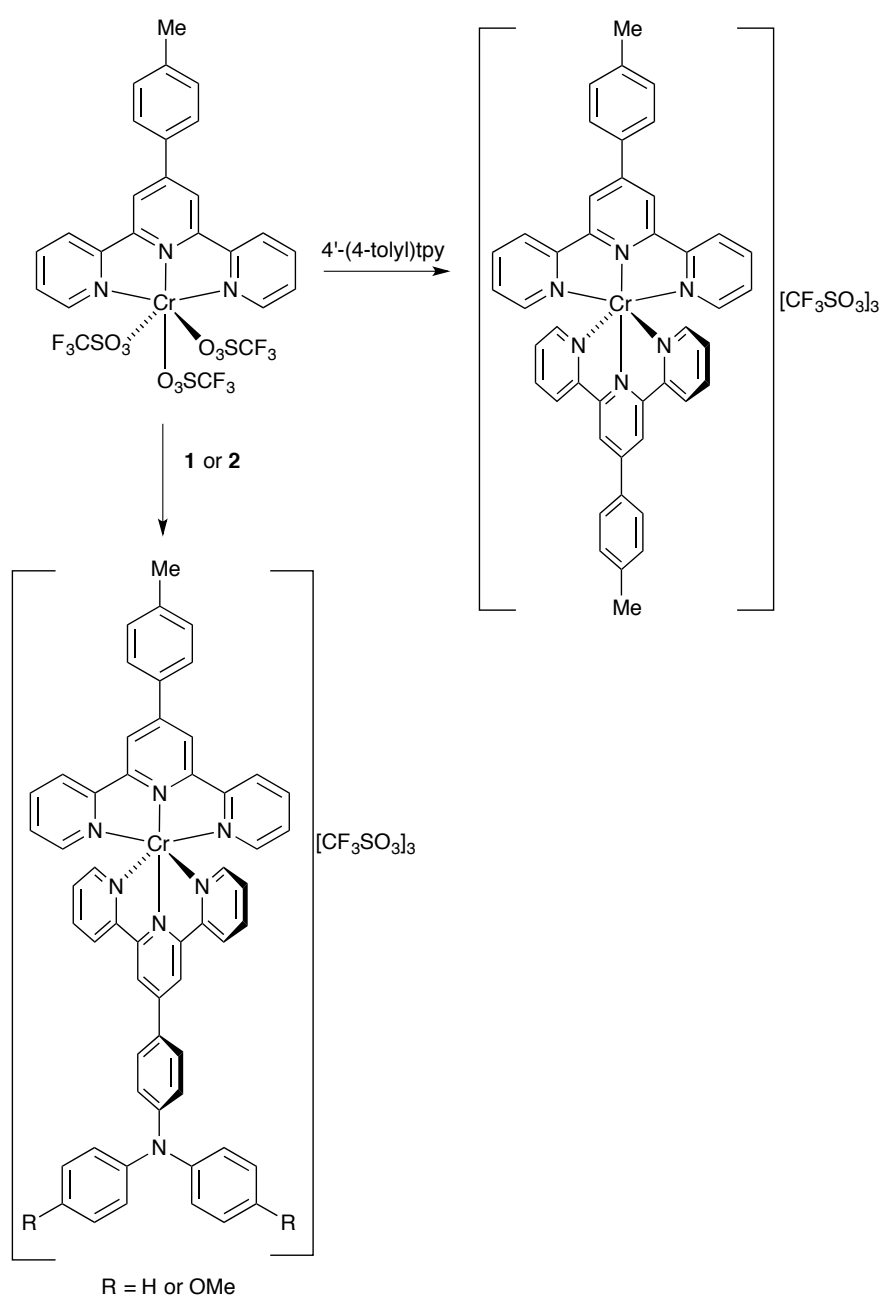

Scheme 3. Synthetic routes to $\left[\mathrm{Cr}\left(4^{\prime}-(4-\text { tolyl }) \text { tpy }\right)_{2}\right]\left[\mathrm{CF}_{3} \mathrm{SO}_{3}\right]_{3},\left[\mathrm{Cr}(\mathbf{1})\left(4^{\prime}-(4-\right.\right.$ tolyl)tpy) $]\left[\mathrm{CF}_{3} \mathrm{SO}_{3}\right]_{3}$ and $\left[\mathrm{Cr}(2)\left(4 '-(4-\right.\right.$ tolyl)tpy) $]\left[\mathrm{CF}_{3} \mathrm{SO}_{3}\right]_{3}$. 


\subsection{Crystal structure of $\left[\mathrm{Cr}\left(4^{\prime}-(4-\text { tolyl)tpy) })_{2}\right]\left[\mathrm{CF}_{3} \mathrm{SO}_{3}\right]_{3} \cdot 2 \mathrm{MeCN}\right.$}

Structural data for complexes containing $\left\{\mathrm{Cr}(\operatorname{tpy})_{2}\right\}$ domains are surprisingly few. The Cambridge Structural Database [26] (searched using Conquest v. 1.16 [24], CSD v. 5.35 with updates up to May 2014) contains only seven examples, four of which contain chromium(III) $[17,18,19]$. The structure of the $\left[\mathrm{Cr}\left(4^{\prime}-(4-\text { tolyl)tpy })_{2}\right]^{3+}\right.$ cation (Figure 1$)$ was confirmed by a single crystal determination of $\left[\mathrm{Cr}(4 \text { '-(4-tolyl)tpy) })_{2}\right]\left[\mathrm{CF}_{3} \mathrm{SO}_{3}\right]_{3} \cdot 2 \mathrm{MeCN}$. The crystals were grown serendipitously from a $\mathrm{MeOH}$ solution of the crude product of a trial reaction of $\left[\mathrm{Cr}\left(4^{\prime}\right.\right.$-(4-tolyl)tpy) $\left.\left(\mathrm{CF}_{3} \mathrm{SO}_{3}\right)_{3}\right]$ with 5,5"-dimethyl-2,2':6',2"-terpyridine (5,5"-- $\mathrm{Me}_{2}$ tpy) in $\mathrm{MeCN}$ under microwave conditions $\left(150^{\circ} \mathrm{C}, 11\right.$ bar); crystals grew after slow evaporation of solvent over a period of several weeks. The isolation of the homoleptic complex rather than the target $\left[\mathrm{Cr}\left(4^{\prime}-\left(4-\right.\right.\right.$ tolyl)tpy)(5,5"-- $\mathrm{Me}_{2}$ tpy) $]\left[\mathrm{CF}_{3} \mathrm{SO}_{3}\right]_{3}$ can be understood in terms of lability of the ligands in $\left[\mathrm{Cr}(\operatorname{tpy})_{2}\right]^{3+}$ complexes [19]. [ $\mathrm{Cr}\left(4^{\prime}-(4-\right.$ tolyl)tpy $\left.)_{2}\right]\left[\mathrm{CF}_{3} \mathrm{SO}_{3}\right]_{3} \cdot 2 \mathrm{MeCN}$ crystallizes in the monoclinic space group $C 2 / c$, and the asymmetric unit contains half of the cation, the other half being generated by rotation about a 2-fold axis. The asymmetric unit also contains one ordered $\left[\mathrm{CF}_{3} \mathrm{SO}_{3}\right]^{-}$ion, one half-occupancy, disordered anion which lies on a 2-fold axis, and one ordered MeCN molecule. The bond distances and angles in the coordination sphere of atom Cr1 (caption to Figure 1) are comparable with those in $\left[\mathrm{Cr}\left(\text { tpy)(4'-(4-tolyl)tpy)][} \mathrm{PF}_{6}\right]_{3} \cdot 3 \mathrm{MeCN}\right.$ [19]. The phenyl ring is twisted through $18.5^{\circ}$ with respect to the plane of the pyridine ring containing C8, and this compares to $24.4^{\circ}$ in $\left[\mathrm{Cr}(\operatorname{tpy})\left(4^{\prime}-(4-\text { tolyl }) \text { tpy) }\right]^{3+}[19]\right.$, and with $29.2^{\circ}$ and $16.0^{\circ}$ or $28.7^{\circ}$ and $27.8^{\circ}$ for the two independent molecules in each of the two polymorphs of the free 4'-(4-tolyl)tpy ligand [27,28]. 


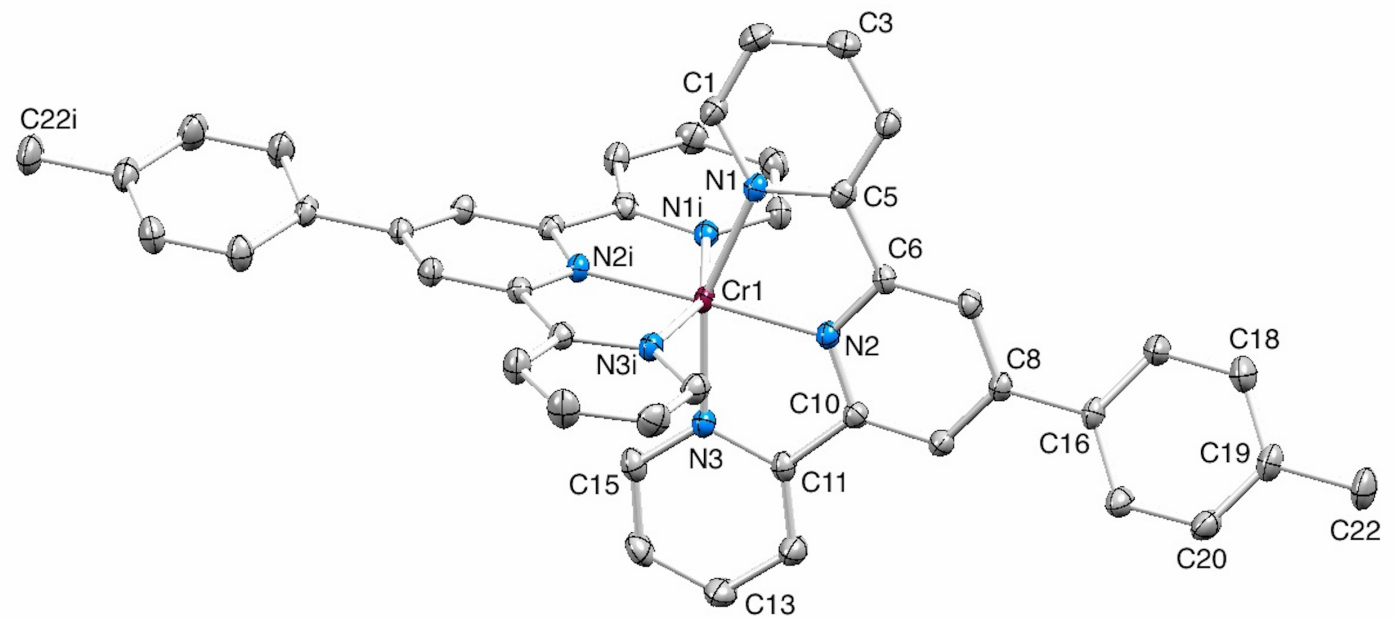

Fig. 1. Structure of the $\left[\mathrm{Cr}\left(4^{\prime}-(4-\text { tolyl }) \text { tpy }\right)_{2}\right]^{3+}$ cation in $\left[\mathrm{Cr}\left(4^{\prime}-(4-\right.\right.$ tolyl)tpy) $\left.{ }_{2}\right]\left[\mathrm{CF}_{3} \mathrm{SO}_{3}\right]_{3} \cdot 2 \mathrm{MeCN}$ (ellipsoids plotted at $50 \%$ probability level and $\mathrm{H}$ atoms omitted for clarity). Important bond distances and angles: $\mathrm{Cr} 1-\mathrm{N} 1=2.061(2), \mathrm{Cr} 1-\mathrm{N} 2=$ 1.9717(18), Cr1-N3 = 2.055(2) Å; N2-Cr1-N1 = 78.79(8), N2-Cr1-N3 = 78.59(8), N2$\mathrm{Cr} 1-\mathrm{N} 2^{\mathrm{i}}=177.92(11)^{\mathrm{o}}($ symmetry code $\mathrm{i}=1-x, y, 1 / 2-z)$.

The packing of cations in $\left[\mathrm{Cr}(4 \text { '-(4-tolyl)tpy })_{2}\right]\left[\mathrm{CF}_{3} \mathrm{SO}_{3}\right]_{3} \cdot 2 \mathrm{MeCN}$ involves multiple embraces [29]. Figure 2a depicts the principal packing motif, comprising a head-to-tail $\pi$ stacking interaction between centrosymmetric pairs of cations. The pyridine ring containing N3 stacks over the arene ring of the tolyl substituent containing atom C19 ${ }^{\mathrm{ii}}$ (symmetry code $\mathrm{ii}=1-x,-y, 1-z$ ). The inter-centroid distance is $3.71 \AA$, and the angle between the ring planes is $17.4^{\circ}$. Propagaton of this motif results in the assembly of chains that follow the crystallographic $c$-axis (Figure $2 b$ ), although there are no close $\pi$-contacts between chains. This is seen in Figure $2 \mathrm{c}$ which views four adjacent chains, the cavities between which are occupied by the triflate anions and $\mathrm{MeCN}$ molecules. 


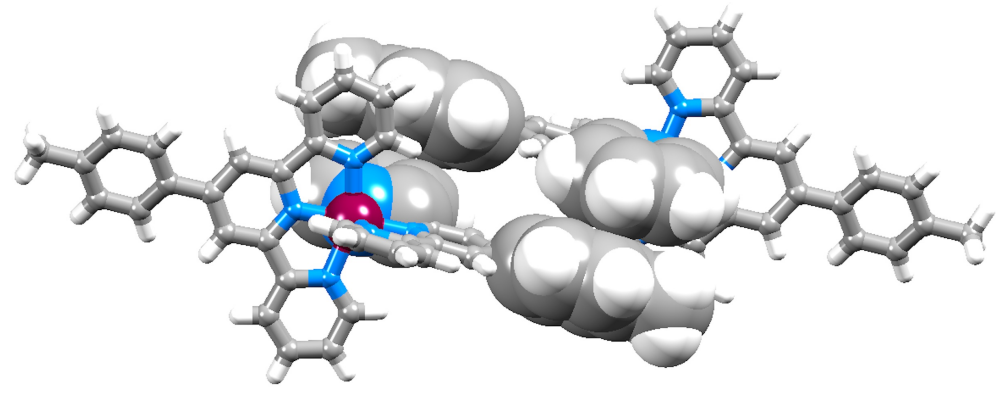

(a)

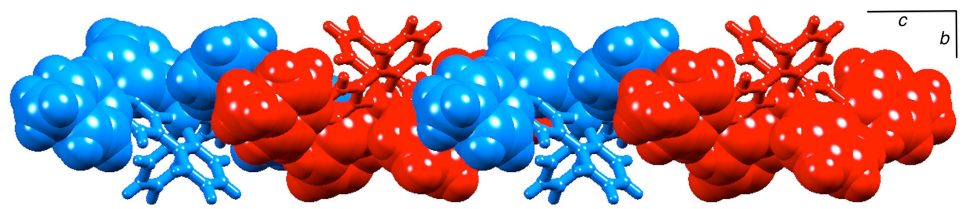

(b)

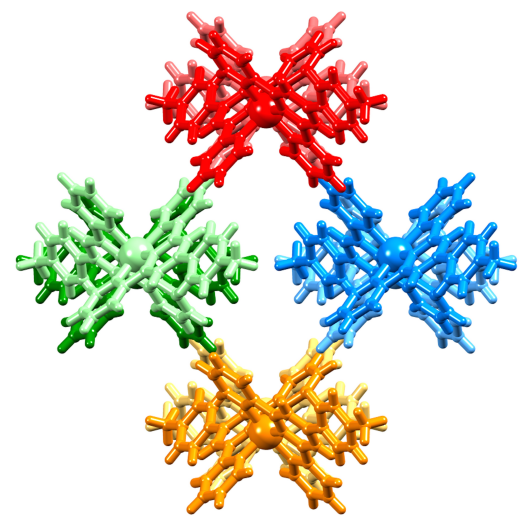

(c)

Figure 2. (a) Centrosymmetric head-to-tail embrace of $\left[\mathrm{Cr}\left(4^{\prime}-(4-\text { tolyl)tpy })_{2}\right]^{3+}\right.$ cations. Assembly of chains along the $c$-axis; adjacent molecules are coloured red and blue. (c) Four adjacent chains viewed down the $c$-axis. (Colour online)

The interactions between cations in $\left[\mathrm{Cr}(4 \text { '-(4-tolyl)tpy })_{2}\right]\left[\mathrm{CF}_{3} \mathrm{SO}_{3}\right]_{3} \cdot 2 \mathrm{MeCN}$ contrasts dramatically with the motifs observed in $\left[\mathrm{Fe}(4 \text { '-(4-tolyl)tpy })_{2}\right]\left[\mathrm{PF}_{6}\right]_{2} \cdot 2.2 \mathrm{MeCN}$ and $\left[\mathrm{Ru}(4 \text { '-(4-tolyl)tpy })_{2}\right]\left[\mathrm{PF}_{6}\right]_{2} \cdot 1.75 \mathrm{MeCN}$ in which the cations pack into rows with faceto-face $\pi$-interactions between pairs of outer pyridine rings [28]. In order to ascertain whether this change in structural paradigm is associated with the change in oxidation state of the metal, we have considered other structurally determined [M(4'-(4-tolyl)tpy $\left.)_{2}\right]^{3+}$ complexes. 
The space group and cell dimensions for $\left[\mathrm{Cr}\left(4^{\prime}-(4-\text { tolyl)tpy) })_{2}\right]\left[\mathrm{CF}_{3} \mathrm{SO}_{3}\right]_{3} \cdot 2 \mathrm{MeCN}\right.$ $\left(C 2 / c, a=14.5535(8), b=17.1633(11), c=21.9247(14) \AA, \beta=108.308(4)^{\circ}\right)$ are very similar to those for $\left[\mathrm{Mn}\left(4^{\prime}-(4-\text { tolyl)tpy })_{2}\right]\left[\mathrm{PF}_{6}\right]_{3} \cdot 2 \mathrm{MeCN}\right.$ (CSD refcode QOQJOW, $C 2 / c, a$ $=14.788(2), b=16.140(2), c=21.467(3) \AA, \beta=105.93(1)^{\circ}[30]$ and $\left[\operatorname{Ir}\left(4^{\prime}-(4-\right.\right.$ tolyl)tpy) $\left.)_{2}\right]\left[\mathrm{PF}_{6}\right]_{3} \cdot 2 \mathrm{MeCN}$ (refcode YIDAU01, $C 2 / c, a=14.7995(5), b=16.4658(5), c=$ 21.5521(7) $\AA, \beta=105.5450(8)^{\circ}$ [31], and YIDAU02, $C 2 / c, a=14.6977(14), b=$ 16.3737(16), $\left.c=21.420(2) \AA, \beta=105.639(2)^{\circ}[32]\right)$. An additional determination for $\left[\operatorname{Ir}(4 \text { '-(4-tolyl)tpy })_{2}\right]\left[\mathrm{PF}_{6}\right]_{3} \cdot 2 \mathrm{MeCN}$ (refcode YIDAU) reports that the complex crystallizes in the $C c$ space group with $a=14.7995(5), b=16.4658(5), c=21.5521(7) \AA, \beta=$ $105.5450(8)^{\circ}[33]$. Each of these metal(III) complexes assembles with the same $\pi$-stacked motif shown in Figure 2a, although the change from triflate to hexafluoridophosphate anions causes a shift in the chains from following the $c$-axis to running obiquely through the $a c$-plane. The common assembly motif seen in these metal(III) salts is not present in any of the salts of $\left[\mathrm{M}\left(4^{\prime}-(4-\text { tolyl }) \text { tpy }\right)_{2}\right]^{2+}$ complexes deposited in the CSD (refcodes DIKYIG [30,34], KAYHIC [35], KEMWEG [36], KUWKOD [37] and QOLYUM [38]). These observations suggest that the accommodation of three anions $\left(\left[\mathrm{PF}_{6}\right]^{-}\right.$or $\left.\left[\mathrm{CF}_{3} \mathrm{SO}_{3}\right]^{-}\right)$ and two MeCN molecules per $\left[\mathrm{M}\left(4^{\prime}-(4-\text { tolyl }) \operatorname{tpy}\right)_{2}\right]^{3+}(\mathrm{M}=\mathrm{Mn}, \mathrm{Cr}$ or $\mathrm{Ir})$ leads to a common packing motif.

\subsection{Absorption spectroscopic properties}

Compared to tpy or 4'-(4-tolyl)tpy, the introduction of 4'-(4-( $N, N$-diphenylamino)phenyl) or 4'-(4-(N,N-di(4-methoxyphenyl)amino)phenyl) substituents results in the solution electronic absorption spectra of the free ligands extending into the visible region [21]. The ligands exhibit a characteristic intra-ligand charge transfer (ILCT) band with the tertiary 
amine acting as an electron donor [39]. This charge separation is stabilized by coordination, causing a red-shift in the ILCT band $[39,40]$, as reported for complexes of ruthenium, osmium, iridium, zinc and cadmium containing $\mathbf{1}$ or $\mathbf{2}[21,41,42,43,44,45,46]$. In MeCN solution, the ILCT maxima for $\left[\mathrm{Cr}(\mathbf{1})\left(4^{\prime}-(4-\right.\right.$ tolyl $)$ tpy) $]\left[\mathrm{CF}_{3} \mathrm{SO}_{3}\right]_{3}$ and $\left[\mathrm{Cr}(\mathbf{2})\left(4^{\prime}-\right.\right.$ (4-tolyl)tpy)][CF $\left.\mathrm{CO}_{3}\right]_{3}$ are $507 \mathrm{~nm}\left(\varepsilon=22200 \mathrm{dm}^{3} \mathrm{~mol}^{-1} \mathrm{~cm}^{-1}\right)$ and $523 \mathrm{~nm}(\varepsilon=21100$ $\mathrm{dm}^{3} \mathrm{~mol}^{-1} \mathrm{~cm}^{-1}$ ), respectively, and the solutions are dark red. Figure 3 compares the absorption spectra of $\mathrm{MeCN}$ solutions of $\left[\mathrm{Cr}\left(4^{\prime}-(4-\text { tolyl)tpy })_{2}\right]\left[\mathrm{CF}_{3} \mathrm{SO}_{3}\right]_{3},\left[\mathrm{Cr}(\mathbf{1})\left(4^{\prime}-(4-\right.\right.\right.$ tolyl)tpy) $]\left[\mathrm{CF}_{3} \mathrm{SO}_{3}\right]_{3}$ and $\left[\mathrm{Cr}(2)\left(4^{\prime}-(4-\right.\right.$ tolyl)tpy) $]\left[\mathrm{CF}_{3} \mathrm{SO}_{3}\right]_{3}$. Each of the heteroleptic complexes exhibits a broad, low intensity band $(665 \mathrm{~nm}$ for [Cr(1)(4'-(4tolyl)tpy) $]\left[\mathrm{CF}_{3} \mathrm{SO}_{3}\right]_{3}$ and $708 \mathrm{~nm}$ for $\left[\mathrm{Cr}(2)\left(4 '-(4-\right.\right.$ tolyl)tpy) $\left.]\left[\mathrm{CF}_{3} \mathrm{SO}_{3}\right]_{3}\right)$.

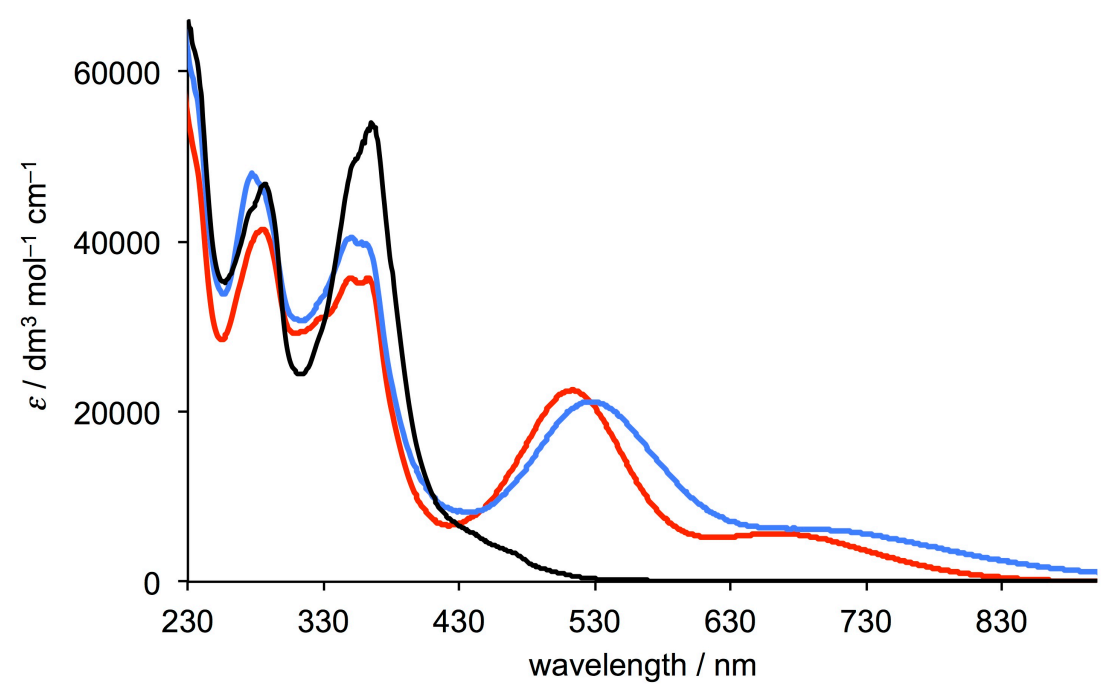

Figure 3. Absorption spectra of solutions of $\left[\mathrm{Cr}\left(4^{\prime}-(4-\text { tolyl)tpy) })_{2}\right]\left[\mathrm{CF}_{3} \mathrm{SO}_{3}\right]_{3}\right.$ (black line), $\left[\mathrm{Cr}(\mathbf{1})\left(4 '-(4-\right.\right.$ tolyl)tpy) $]\left[\mathrm{CF}_{3} \mathrm{SO}_{3}\right]_{3}$ (red line) and $\left[\mathrm{Cr}(2)\left(4 '-(4-\right.\right.$ tolyl)tpy) $]\left[\mathrm{CF}_{3} \mathrm{SO}_{3}\right]_{3}$ (blue line) in $\mathrm{MeCN}\left(5 \times 10^{-5} \mathrm{~mol} \mathrm{dm}^{-3}\right)$.

The ILCT absorption band in the solution spectra of $\left[\mathrm{Cr}(\mathbf{1})\left(4^{\prime}-(4-\right.\right.$ tolyl)tpy) $]\left[\mathrm{CF}_{3} \mathrm{SO}_{3}\right]_{3}$ and $\left[\mathrm{Cr}(2)(4\right.$ '-(4-tolyl)tpy) $]\left[\mathrm{CF}_{3} \mathrm{SO}_{3}\right]_{3}$ shifts to higher energies in solvents of increasing polarity, and we investgated this negative solvatochromism [47] in more detail for $\left[\mathrm{Cr}(2)\left(4 '-\left(4-\text { tolyl)tpy)][CF} \mathrm{CO}_{3}\right]_{3}\right.\right.$. Figure 4 illustrates the shift in $\lambda_{\max }$ from $574 \mathrm{~nm}$ in 
$\mathrm{CHCl}_{3}$ to $526 \mathrm{~nm}$ in $\mathrm{MeCN}$, and the data correlate well with trends in solvent dipole moments and dielectric constants (Table 1).

Table 1 Relationship between $\lambda_{\max }$ for the ILCT band in $\left[\mathrm{Cr}(2)\left(4^{\prime}-(4-\right.\right.$ tolyl)tpy) $]\left[\mathrm{CF}_{3} \mathrm{SO}_{3}\right]_{3}$ and dipole moment and dielectric constant of the solvent.

\begin{tabular}{|l|l|l|l|}
\hline Solvent & $\lambda_{\max } / \mathrm{nm}$ & Dipole moment / D & Dielectric constant \\
\hline $\mathrm{CHCl}_{3}$ & 574 & 1.15 & 4.81 \\
\hline $\mathrm{CH}_{2} \mathrm{Cl}_{2}$ & 563 & 1.14 & 8.93 \\
\hline EtOH & 550 & 1.69 & 24.3 \\
\hline Acetone & 526 & 2.69 & 20.7 \\
\hline $\mathrm{MeCN}$ & 528 & 3.44 & 37.5 \\
\hline
\end{tabular}

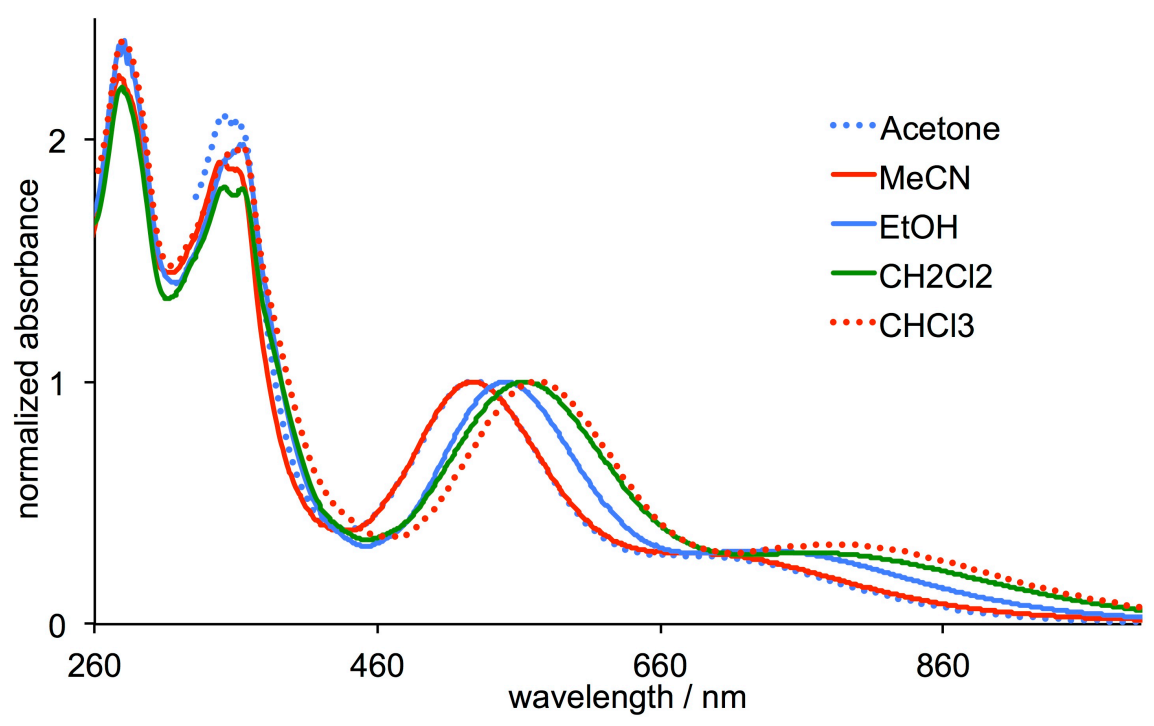

Figure 4. Solution absorption spectra of $\left[\mathrm{Cr}(2)(4\right.$-(4-tolyl)tpy) $]\left[\mathrm{CF}_{3} \mathrm{SO}_{3}\right]_{3}$ in different solvents (concentration $=5 \times 10^{-5} \mathrm{~mol} \mathrm{dm}^{-3}$ ), normalized with respect to the band ca. 500 nm. (Colour on line.)

The absorption spectra of solutions of $\left[\mathrm{Cr}(2)\left(4\right.\right.$ '-(4-tolyl)tpy)] $\left[\mathrm{CF}_{3} \mathrm{SO}_{3}\right]_{3}$ in the solvents shown in Figure 4 did not change when monitored over a period of a week. However, in $\mathrm{H}_{2} \mathrm{O}, \mathrm{MeOH}$, DMSO and DMF, significant changes were observed, indicating that the complexes are not stable in these solvents. Figure 5a illustrates the absorption spectrum of a DMF solution of $\left[\mathrm{Cr}(2)\left(4^{\prime}-(4-\right.\right.$ tolyl)tpy) $]\left[\mathrm{CF}_{3} \mathrm{SO}_{3}\right]_{3}$ monitored over 6 hours; no further change was observed after this period. The ILCT band initially with $\lambda_{\max }=520$ $\mathrm{nm}\left(\varepsilon=11950 \mathrm{dm}^{3} \mathrm{~mol}^{-1} \mathrm{~cm}^{-1}\right)$ decays to a band with $\lambda_{\max }=483 \mathrm{~nm}\left(\varepsilon=6600 \mathrm{dm}^{3} \mathrm{~mol}^{-}\right.$ 
${ }^{1} \mathrm{~cm}^{-1}$ ), and the weaker absorption (initially at $695 \mathrm{~nm}$ ) evolves into a shoulder at $580 \mathrm{~nm}$ (Figure 5b). Several reaction pathways (Scheme 4) can be considered: (i) complete ligand displacement by $\mathrm{DMF}$ to give $\left[\mathrm{Cr}(\mathrm{DMF})_{6}\right]^{3+}$, (ii) partial ligand displacement, or (iii) ligand redistribution to give a mixture of $\left[\mathrm{Cr}(\mathbf{2})\left(4^{\prime}-(4-\text { tolyl }) \operatorname{tpy}\right)\right]^{3+},\left[\mathrm{Cr}(\mathbf{2})_{2}\right]^{3+}$ and $\left[\mathrm{Cr}\left(4^{\prime}-(4-\right.\right.$ tolyl)tpy $\left.)_{2}\right]^{3+}$. Absorptions $>450 \mathrm{~nm}$ can only arise from chromium(III)-containing species. $\left[\mathrm{Cr}(\mathrm{DMF})_{6}\right]^{3+}$ exhibits an absorption at $592 \mathrm{~nm}$ (assigned to the ${ }^{4} \mathrm{~T}_{2 \mathrm{~g}} \leftarrow{ }^{4} \mathrm{~A}_{2 \mathrm{~g}}$ transition and with $\varepsilon=54 \mathrm{dm}^{3} \mathrm{~mol}^{-1} \mathrm{~cm}^{-1}$ ) $[48,49,50]$, but the $\approx 1000$-fold difference in extinction coefficients allows us to eliminate $\left[\mathrm{Cr}(\mathrm{DMF})_{6}\right]^{3+}$ as the origin of the absorption. The lowest energy absorption in the spectrum of a DMF solution of $\mathbf{2}$ appears at $367 \mathrm{~nm}(\varepsilon=22700$ $\mathrm{dm}^{3} \mathrm{~mol}^{-1} \mathrm{~cm}^{-1}$ ). Hence, we assign the absorption at $483 \mathrm{~nm}$ to chromium(III)-bound 2 , rather than free ligand (Figure 5c). The intense absorption at $344 \mathrm{~nm}$ in Figure 5a which loses intensity over time is characteristic of a $\left\{\mathrm{Cr}^{\mathrm{III}}\left(4^{\prime}-(4-\right.\right.$ tolyl)tpy) $\}$ chromophore (Figure 3) [19]. These data, coupled with the increase in intensity of the high energy absorption at $288 \mathrm{~nm}$, are consistent with the lability of both 2 and 4'-(4-tolyl)tpy in DMF. Similar spectral changes are also seen over time for $\mathrm{H}_{2} \mathrm{O}$, DMSO or $\mathrm{MeOH}$ solutions of $\left[\mathrm{Cr}(\mathbf{2})\left(4^{\prime}-\right.\right.$

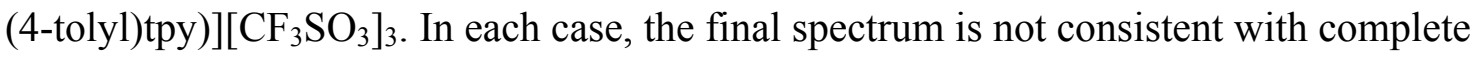
ligand loss (Figure 5c), but rather suggests the presence of a mixture of the solvento complexes $\left[\mathrm{Cr}(\mathbf{2})(\mathrm{Solv})_{3}\right]^{3+}$ and $\left[\mathrm{Cr}\left(4^{\prime}-(4-\text { tolyl }) \text { tpy }\right)(\operatorname{Solv})_{3}\right]^{3+}$ where Solv $=$ solvent. The results are consistent with our previous observations that both ligands in [Cr(tpy)(4'-(4tolyl)tpy) $]\left[\mathrm{PF}_{6}\right]_{3}$ and $\left[\mathrm{Cr}(\mathrm{tpy})\left(5,5 "-\mathrm{Me}_{2} \mathrm{tpy}\right)\right]\left[\mathrm{PF}_{6}\right]_{3}$ are labile in the presence of fluoride ion; in this case we were able to show that the absorption maximum of the final solution corresponded to that reported for $\left[\mathrm{Cr}(\mathrm{tpy}) \mathrm{F}_{3}\right][19,51]$. 


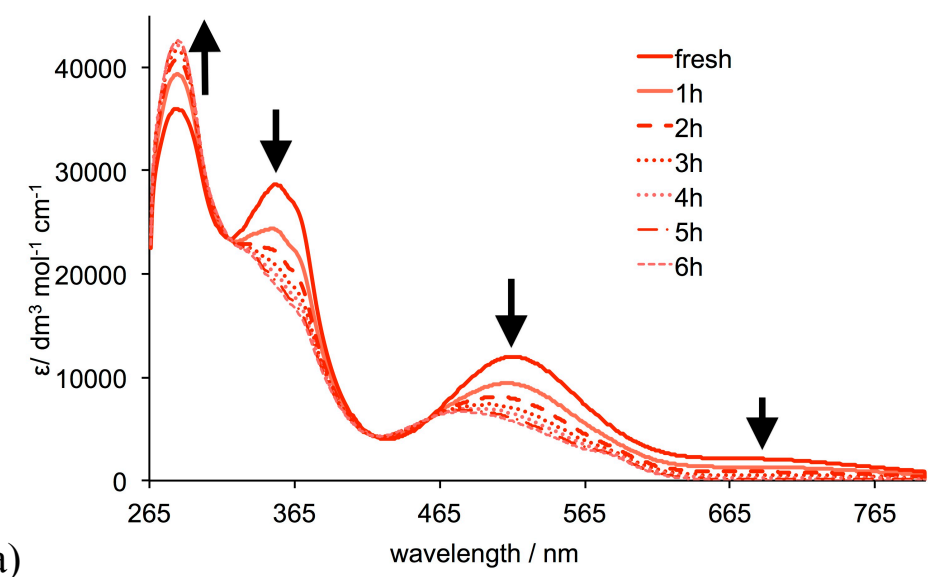

(a)



(b)

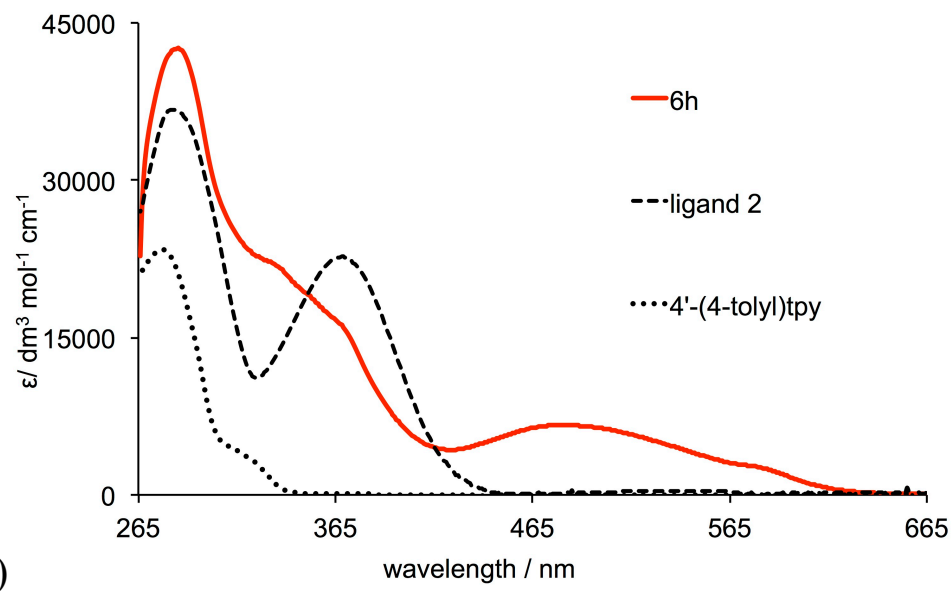

Figure 5. (a) Solution absorption spectra of [Cr(2)(4'-(4-tolyl)tpy)][CF $\left.\mathrm{CF}_{3} \mathrm{SO}_{3}\right]_{3}$ in DMF (concentration $=5 \times 10^{-5} \mathrm{~mol} \mathrm{dm}^{-3}$ ) over a period of 6 hours, and (b) an expansion of the ILCT bands for the initial and final spectra. (c) Comparison of the DMF solution spectra of free ligands 2 and 4'-(4-tolyl)tpy and the aged solution of [Cr(2)(4'-(4-

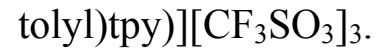




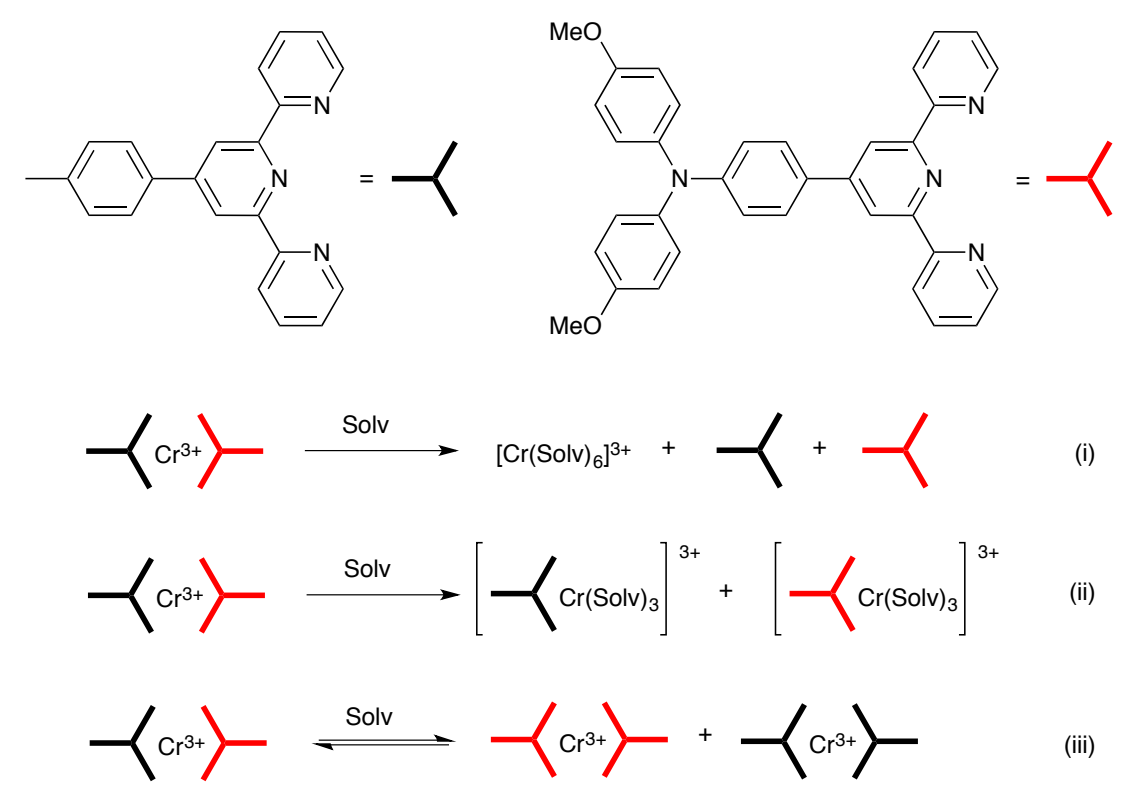

Scheme 4. Possible pathways for the reaction of $\left[\mathrm{Cr}(2)\left(4^{\prime}-(4-\text { tolyl }) \text { tpy }\right)\right]^{3+}$ in DMF, DMSO, $\mathrm{H}_{2} \mathrm{O}$ and $\mathrm{MeOH}$. Experimental data for DMF solutions support pathway (ii).

\subsection{Electrochemistry}

The electrochemical behaviour of homoleptic and heteroleptic complexes containing 1 and 4'-(4-tolyl)tpy was investigated by cyclic voltammetry, and the results are given in Table 2. Wieghardt and coworkers have proposed [7] that the three reversible reduction processes observed for $\left[\mathrm{Cr}(\mathrm{tpy})_{2}\right]^{3+}$ are all ligand based, with stepwise reduction occurring sequentially on one, then the other, ligand. Each of $\left[\mathrm{Cr}(4 \text { '-(4-tolyl)tpy) })_{2}\right]\left[\mathrm{CF}_{3} \mathrm{SO}_{3}\right]_{3}$, $\left[\mathrm{Cr}(\mathbf{1})\left(4^{\prime}-(4-\right.\right.$ tolyl $\left.\left.) \operatorname{tpy}\right)\right]\left[\mathrm{CF}_{3} \mathrm{SO}_{3}\right]_{3}$ and $\left[\mathrm{Cr}(\mathbf{1})_{2}\right]\left[\mathrm{CF}_{3} \mathrm{SO}_{3}\right]_{3}$ also exhibits three reversible reductions, and in addition, the complexes containing 1 exhibit a reversible oxidation (Table 2). The latter is presumably centred on the diphenylamine unit. The first reduction step occurs at increasingly more negative potential on going from $\left[\mathrm{Cr}(\operatorname{tpy})_{2}\right]^{3+}$ to $\left[\mathrm{Cr}\left(4^{\prime}-(4-\right.\right.$ tolyl)tpy $\left.)_{2}\right]^{3+}$ and $\left[\operatorname{Cr}(\mathbf{1})\left(4^{\prime}-(4-\text { tolyl }) \text { tpy }\right)\right]^{3+}$ to $\left[\operatorname{Cr}(\mathbf{1})_{2}\right]^{3+}$, and the similarity of the first reduction potentials for $\left[\mathrm{Cr}\left(4^{\prime}-(4-\text { tolyl }) \text { tpy }\right)_{2}\right]^{3+}$ and $\left[\mathrm{Cr}(\mathbf{1})\left(4^{\prime}-(4-\text { tolyl }) \text { tpy) }\right]^{3+}\right.$ suggests that the 4'-(4-tolyl)tpy ligand is the first to be reduced in the heteroleptic complex. 
Table 2 Cyclic voltammetric data with respect to $\mathrm{Fc} / \mathrm{Fc}^{+} ; \mathrm{MeCN}$ solutions with $\left[{ }^{\mathrm{n}} \mathrm{Bu}_{4} \mathrm{~N}\right]\left[\mathrm{PF}_{6}\right]$ supporting electrolyte, and scan rate of $0.1 \mathrm{~V} \mathrm{~s}^{-1}$.

\begin{tabular}{|c|c|c|c|c|}
\hline Compound & $E_{1 / 2}^{\mathrm{ox}}{ }^{4+/ 3+} / \mathrm{V}$ & $E_{1 / 2}^{\mathrm{red}}{ }^{3+/ 2+} / \mathrm{V}$ & $E_{1 / 2}^{\mathrm{red}}{ }^{2+/ 1+} / \mathrm{V}$ & $E_{1 / 2}^{\mathrm{red}}{ }^{1+/ 0} / \mathrm{V}$ \\
\hline$\left[\mathrm{Cr}(\mathrm{tpy})_{2}\right]\left[\mathrm{PF}_{6}\right]_{3}{ }^{\mathrm{a}}$ & & -0.533 & -0.953 & -1.469 \\
\hline$\left[\mathrm{Cr}\left(4^{\prime}-(4 \text {-tolyl }) \operatorname{tpy}\right)_{2}\right]\left[\mathrm{CF}_{3} \mathrm{SO}_{3}\right]_{3}$ & & -0.581 & -0.949 & -1.278 \\
\hline$\left[\mathrm{Cr}(\mathbf{1})\left(4^{\prime}-(4\right.\right.$-tolyl)tpy) $]\left[\mathrm{CF}_{3} \mathrm{SO}_{3}\right]_{3}$ & +0.660 & -0.587 & -0.955 & -1.276 \\
\hline$\left[\mathrm{Cr}(\mathbf{1})_{2}\right]\left[\mathrm{CF}_{3} \mathrm{SO}_{3}\right]_{3}$ & +0.683 & -0.601 & -0.955 & -1.431 \\
\hline
\end{tabular}

a Data from reference [19].

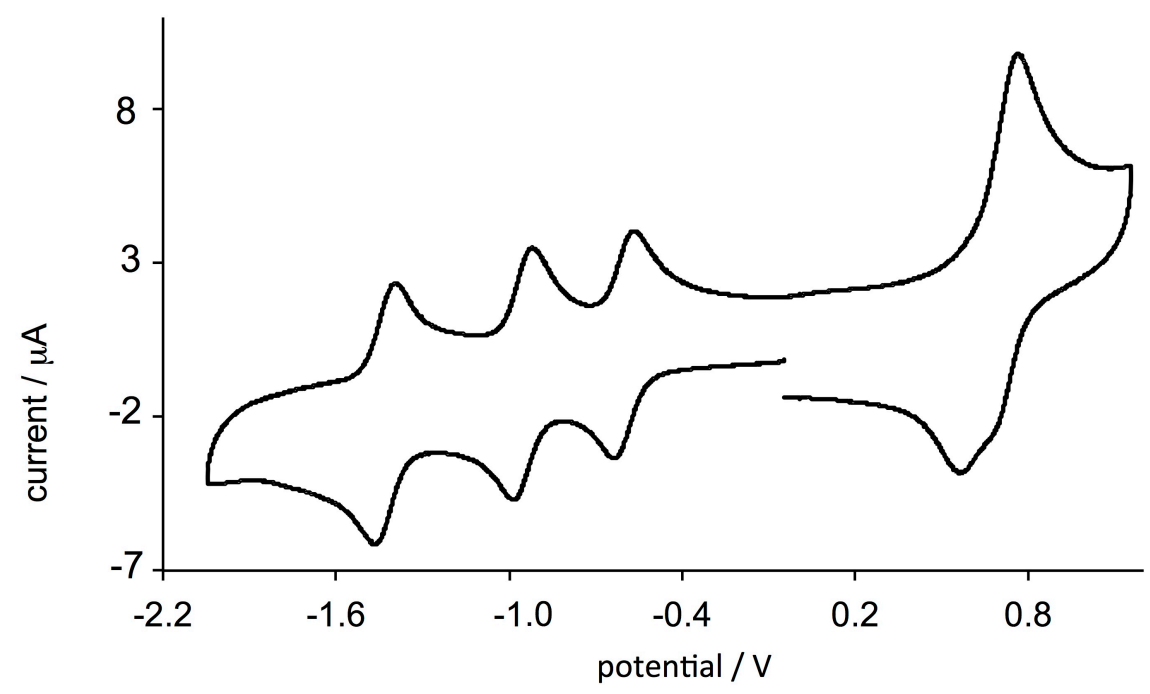

Figure 6. Cyclic voltammogram of $\left[\mathrm{Cr}(\mathbf{1})_{2}\right]\left[\mathrm{CF}_{3} \mathrm{SO}_{3}\right]_{3}$, measured in $\mathrm{MeCN}$ (with respect to $\mathrm{Fc} / \mathrm{Fc}^{+}$, with $\left[{ }^{\mathrm{n}} \mathrm{Bu}_{4} \mathrm{~N}\right]\left[\mathrm{PF}_{6}\right]$ as supporting electrolyte at a scan rate of $0.1 \mathrm{~V} \mathrm{~s}^{-1}$ ).

\section{$4 \quad$ Conclusions}

We have prepared and characterized $\left[\mathrm{Cr}(\mathbf{1})\left(4 \text { '-(4-tolyl)tpy)][CF} 3 \mathrm{SO}_{3}\right]_{3}\right.$ and $[\mathrm{Cr}(\mathbf{2})(4$ '-(4-

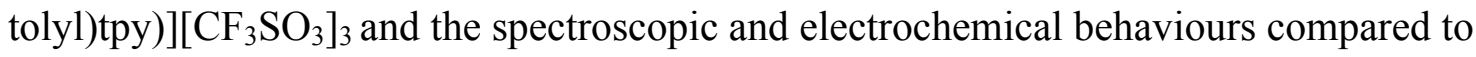
those of $\left[\mathrm{Cr}\left(4^{\prime}-(4-\text { tolyl)tpy })_{2}\right]\left[\mathrm{CF}_{3} \mathrm{SO}_{3}\right]_{3}\right.$ and $\left[\mathrm{Cr}(\mathbf{1})_{2}\right]\left[\mathrm{CF}_{3} \mathrm{SO}_{3}\right]_{3}$. The single crystal structure of $\left[\mathrm{Cr}\left(4^{\prime}-(4 \text {-tolyl)tpy) })_{2}\right]\left[\mathrm{CF}_{3} \mathrm{SO}_{3}\right]_{3} \cdot 2 \mathrm{MeCN}\right.$ reveals packing features which result from the need to accommodate three anions and two solvent molecules per cation; embraces 
between cations differ from those observed with salts of $\left[\mathrm{M}\left(4^{\prime}-(4-\text { tolyl }) \operatorname{tpy}\right)_{2}\right]^{2+}$. The characteristic ILCT absorption of $\mathbf{1}$ or $\mathbf{2}$ is red-shifted upon coordination to $\mathrm{Cr}^{3+}$ ions, and exhibits a negative solvatochromic effect. In $\mathrm{CHCl}_{3}, \mathrm{CH}_{2} \mathrm{Cl}_{2}, \mathrm{MeCN}$, acetone or EtOH, $\left[\mathrm{Cr}(\mathbf{1})\left(4^{\prime}-(4-\right.\right.$ tolyl)tpy) $]\left[\mathrm{CF}_{3} \mathrm{SO}_{3}\right]_{3}$ and $\left[\mathrm{Cr}(2)\left(4 \text { '-(4-tolyl)tpy)][CF} \mathrm{CF}_{3} \mathrm{SO}_{3}\right]_{3}\right.$ appear to be stable, but in $\mathrm{H}_{2} \mathrm{O}, \mathrm{MeOH}$, DMSO and DMF, the tpy ligands are labile. Changes in the absorption spectra of $\left[\mathrm{Cr}(2)(4\right.$ '-(4-tolyl)tpy) $]\left[\mathrm{CF}_{3} \mathrm{SO}_{3}\right]_{3}$ in DMF over time are consistent with the formation of $\left[\mathrm{Cr}\left(4^{\prime}-\mathrm{Xtpy}\right)(\mathrm{DMF})_{3}\right]^{3+}$ rather than complete ligand displacement or a ligand redistribution.

\section{Acknowledgements}

We thank the European Research Council (Advanced Grant 267816 LiLo), the Swiss National Science Foundation (grant number 200020_144500) and the University of Basel for financial support.

Appendix

Crystallographic data have been deposited with the CCDC (Cambridge Crystallographic Data Centre, 12 Union Road, Cambridge CB2 1EZ, UK; fax +44 1223336 033; e-mail: deposit@ccdc.cam.ac.uk or www: http://www.ccdc.cam.ac.uk) and may be obtained free of charge on quoting the deposition numbers CCDC 1030355.

\section{References}

[1] M. C. Hughes, D. J. Macero, Inorg. Chim. Acta 4 (1970) 327.

[2] M. C. Hughes, D. J. Macero, Inorg. Chem. 15 (1976) 2040.

[3] H. Behrens, A. Mueller, Z. Anorg. Allg., Chem. 341 (1965) 124.

[4] H. Behrens, U. Anders, Z. Naturforsch. 19B (1964) 767.

[5] H. Behrens, K. Meyer, A. Mueller, Z. Naturforsch. 20B (1965) 74. 
[6] S. Herzog, H. Aul, Z. Chem. 6 (1966) 382.

[7] C. G. Scarborough, K. M. Lancaster, S. DeBeer, T. Weyhermüller, S. Sproules. K. Wieghardt, Inorg. Chem. 51 (2012) 3718.

[8] M. C. Hughes, D. J. Macero, J. M. Rao, Inorg. Chim. Acta 49 (1981) 241.

[9] J. M. Rao, M. C. Hughes, D. J. Macero, Inorg. Chim. Acta 18 (1976) 127.

[10] V. G. Vaidyanathan, B. U. Nair, Eur. J. Inorg. Chem. (2004) 1840.

[11] R. P. Bonomo, S. Musumeci, E. Rizzarelli, S. Sammartano, Gazz. Chim. Ital. 104 (1974) 1067.

[12] N. Serpone, M. A. Jamieson, M. S. Henry, M. Z. Hoffman, F. Bolletta, M. Maestri, J. Am. Chem. Soc. 101 (1979) 2907.

[13] S. R. Allsopp, A. Cox, T. J. Kemp, W. J. Reed, S. Sostero, O. Traverso, J. Chem. Soc., Faraday Trans. 176 (1980) 162.

[14] H. Riesen, L. Wallace, PhysChemComm 6 (2003) 9.

[15] P. B. Lutz, G. J. Long, W. A. Baker, Jr., Inorg. Chem. 8 (1969) 2529.

[16] C. K. Ryu, R. B. Lessard, D. Lynch, J. F. Endicott, J. Phys. Chem. 93 (1989) 1752.

[17] W. A. Wickramasinghe, P. H. Bird, M. A. Jamieson, N. Serpone, Chem. Commun. (1979) 798.

[18] W. A. Wickramasinghe, P. H. Bird, N. Serpone, Inorg. Chem. 21 (1982) 2694

[19] E. C. Constable, C. E. Housecroft, M. Neuburger, J. Schönle, J. A. Zampese, Dalton Trans. 43 (2014) 7227.

[20] J. Wang, G. S. Hanan, Synlett (2005) 1251.

[21] B. Bozic-Weber, E. C. Constable, N. Hostettler, C. E. Housecroft, R. Schmitt, E. Schönhofer, Chem. Commun. 48 (2012) 5727. 
[22] Bruker Analytical X-ray Systems, Inc., 2006, APEX2, version 2 User Manual, M86-E01078, Madison, WI.

[23] G. M. Sheldrick, Acta Crystallogr., Sect. A 64 (2008) 112.

[24] I. J. Bruno, J. C. Cole, P. R. Edgington, M. K. Kessler, C. F. Macrae, P. McCabe, J. Pearson, R. Taylor, Acta Crystallogr., Sect. B 58 (2002) 389.

[25] C. F. Macrae, I. J. Bruno, J. A. Chisholm, P. R. Edgington, P. McCabe, E. Pidcock, L. Rodriguez-Monge, R. Taylor, J. van de Streek, P. A. Wood, J. Appl. Cryst., 41 (2008) 466.

[26] F. H. Allen, Acta Crystallogr., Sect. B 58 (2002) 380.

[27] H.-G. Liu, Y.-C. Qiu, J.-Z. Wu, Acta Crystallogr., Sect. E 63 (2007) o4876.

[28] J. E. Beves, P. Chwalisz, E. C. Constable, C. E. Housecroft, M. Neuburger, S. Schaffner, J. A. Zampese, Inorg. Chem. Comm. 11 (2008) 1009.

[29] J. McMurtie, I. Dance, CrystEngComm 12 (2010) 3207.

[30] S. Romain, C. Duboc, F. Neese, E. Riviere, L. R. Hanton, A. G. Blackman, C. Philouze, J.-C. Leperte, A. Deronzier, M.-N. Collomb, Chem. Eur. J. 15 (2009) 980.

[31] R. E. Marsh, Acta Crystallogr., Sect.B 65 (2009) 782.

[32] L. M. Hinkle, V. G. Young Jr., K. R. Mann, Acta Crystallogr., Sect.C 66 (2010) $\mathrm{m} 62$.

[33] N. Yoshikawa, S. Yamabe, N. Kanehisa, Y. Kai, H. Takashima, K. Tsukahara, Eur. J. Inorg. Chem. (2007) 1911.

[34] H.-G. Liu, Y.-C. Qiu, J.-Z. Wu, Acta Crystallogr., Sect.E 63 (2007) m2393.

[35] V. Uma, V. G. Vaidyanathan, B. U. Nair, Bull. Chem. Soc. Jpn. 78 (2005) 845.

[36] L. Saghatforoush, K. Adil, M. Hasanzadeh, A. Aminkhani, S. Safarinezhad, Acta 
Chim. Slov. 59 (2012) 322.

[37] Q. Jiang, J. Zhu, Y. Zhang, N. Xiao, Z. Guo, BioMetals 22 (2009) 297.

[38] M. Sjödin, J. Gätjens, L. C. Tabares, P. Thuery, V. L. Pecoraro, S. Un, Inorg. Chem. 47 (2008) 2897.

[39] K. A. Walters, Y.-J. Kim, J. T. Hupp, J. Electroanal. Chem. 554-555 (2003) 449.

[40] J. F. Michalec, S. A. Bejune, D. G. Cuttell, G. C. Summerton, J. A. Gertenbach, J. S. Field, R. J. Haines, D. R. McMillin, Inorg. Chem. 40 (2001) 2193.

[41] L. Xiao, Y. Xu, M. Yan, D. Galipeau, X. Peng, X. Yan, J. Phys. Chem. A 114 (2010) 9090.

[42] K. C. D. Robson, B. D. Koivisto, T. J. Gordon, T. Baumgartner, C. P. Berlinguette, Inorg. Chem. 49 (2010) 5335.

[43] J. Collin, S. Guillerez, J.-P. Sauvage, F. Barigelletti, L. Flamigni, L. De Cola, V. Balzani, Coord. Chem. Rev. 111 (1991) 291.

[44] W. Leslie, R. A. Poole, P. R. Murray, L. J. Yellowlees, A. Beeby, J. A. G. Williams, Polyhedron 23 (2004) 2769.

[45] E. Baranoff, I. M. Dixon, J.-P. Collin, J.-P. Sauvage, B. Ventura, L. Flamigni, Inorg. Chem. 43 (2004) 3057.

[46] X. Chen, Q. Zhou, Y. Cheng, Y. Geng, D. Ma, Z. Xie, L. Wang, J. Lumin. 126 (2007) 81 .

[47] C. Reichardt, Chem. Rev. 94 (1994) 2319.

[48] W. Schneider, Helv. Chim. Acta 46 (1963) 1842.

[49] R. R. Windolph, A. J. Leffler, Inorg. Chem. 11 (1972) 594.

[50] S. T. D. Lo, T. W. Swaddle, Inorg. Chem. 15 (1976) 1881. 
[51] T. Birk, M. J. Magnussen, S. Piligkos, H. Weihe, A. Holten, J. Bendix, J. Fluorine Chem. 131 (2010) 898. 